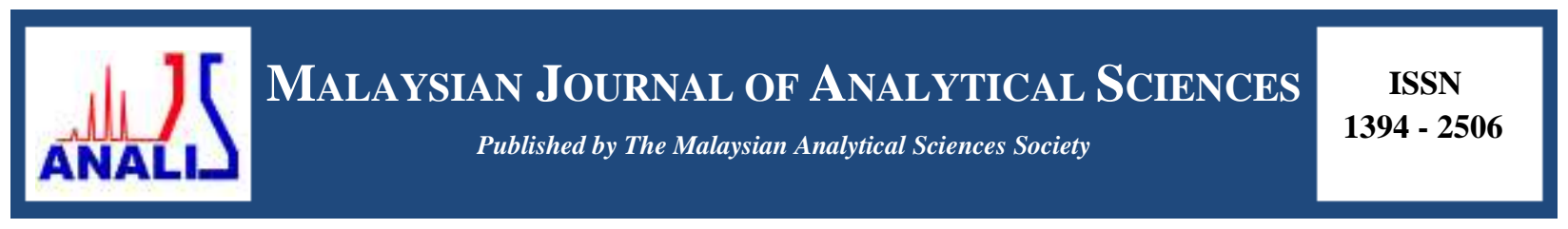

\title{
DITHIZONE MODIFIED SILVER ELECTRODE FOR THE DETERMINATION OF METAL IONS IN AQUEOUS SOLUTION
}

\author{
(Elektrod Perak Diubahsuai Ditizon bagi Penentuan Ion Logam dalam Larutan Akues) \\ Mohamad Aiman Firdaus Othman, Azrilawani Ahmad @ Othman, Hafiza Mohamed Zuki* \\ School of Marine Science and Environment, \\ Universiti Malaysia Terengganu, 21030, Kuala Terengganu, Malaysia \\ *Corresponding author: hafiza@umt.edu.my
}

Received: 9 December 2014; Accepted: 16 October 2015

\begin{abstract}
Dithizone-PVC membrane was constructed and utilized as an ionophore reagent material for chemically modified silver (Ag) electrode. The modified electrode was characterized using cyclic voltammetry where the electrochemical behaviour of dithizone modified $\mathrm{Ag}$ electrode surface was investigated in the range of -0.6 to $+0.6 \mathrm{~V}$ with $0.1 \mathrm{M} \mathrm{KCl}$ as supporting electrolyte. Comparative studies towards metal ions $\mathrm{Cu}^{2+}, \mathrm{Fe}^{2+}$ and $\mathrm{Pb}^{2+}$ exhibited good responses for redox reactions with linear relationship between peak currents and concentrations. The correlation coefficients obtained were $0.9800,0.9944$ and 0.9949 while the evaluated limits of detection were $8.3 \times 10^{-7} \mathrm{M}, 4.7 \times 10^{-7} \mathrm{M}$ and $7.6 \times 10^{-7} \mathrm{M}$ respectively.
\end{abstract}

Keywords: PVC membrane, dithizone (1,5-diphenylthiocarbazone), cyclic voltammetry, redox reactions

\begin{abstract}
Abstrak
Membran PVC-Ditizon telah dibina dan digunakan sebagai bahan reagen ionofora bagi elektrod perak (Ag) yang diubahsuai secara kimia. Elektrod yang diubahsuai telah dicirikan menggunakan voltametri berkitar di mana sifat elektrokimia bagi ditizon yang diubahsuai pada permukaan elektrod $\mathrm{Ag}$ telah dikaji di dalam julat $-0.6 \mathrm{ke}+0.6 \mathrm{~V}$ dengan $0.1 \mathrm{M} \mathrm{KCl}$ sebagai elektrolit sokongan. Kajian perbandingan terhadap ion-ion logam $\mathrm{Cu}^{2+}, \mathrm{Fe}^{2+}$ dan $\mathrm{Pb}^{2+}$ mempamerkan respon yang baik bagi tindak balas redoks dengan hubungan linear antara arus-arus puncak dan kepekatan. Pekali korelasi yang diperolehi adalah $0.9800,0.9944$ dan 0.9949 manakala had pengesanan yang diukur adalah $8.3 \times 10^{-7} \mathrm{M}, 4.7 \times 10^{-7} \mathrm{M}$ dan $7.6 \times 10^{-7} \mathrm{M}$ masing-masing.
\end{abstract}

Kata kunci: membran PVC, ditizon (1,5-difeniltiokarbazon), voltametri berkitar, tindakbalas redoks

\section{Introduction}

Heavy metals pollution in environment is a global issue that has been discussed over the years. Heavy metals can enter the environment by both natural and anthropogenic sources including mining, agrochemicals, sewage and sludge applications and also industrial activity. Copper $\left(\mathrm{Cu}^{2+}\right)$, iron $\left(\mathrm{Fe}^{2+}\right)$ and lead $\left(\mathrm{Pb}^{2+}\right)$ are the most common existence of toxic metal ions in aqueous environmental solution. Although metal ions such as $\mathrm{Cu}^{2+}$ and $\mathrm{Fe}^{2+}$ are categorized as micronutrients at low concentrations, however, in excess contamination, these metals can be highly toxic [1].

Since the last few decades, the need to determine these heavy metal ions in aqueous environments has been highly focused especially in the field of environmental, pharmaceutical and biomedical studies [2,3]. Electrochemical techniques in particular, chemically modified electrodes have received a great deal of attentions for determination of heavy metal ions [4]. These modified electrodes were prepared in varieties of specific modification processes in 
order to improve the sensitivity and specification of the sensing purposes. Different modification processes such as physisorption [5], chemisorption [6], covalent attachment [7], modified polymers [8] and bulk modification of carbon composite materials [9] have been reported. In this study, surface modification of the electrode via polymerized chemisorption coating was applied using the specific and selective dithizone reagent. This method provides a particular function on the electrode surface such as a medium for metal ion bonding and unique properties of metal complexes [10].

Dithizone or 1,5-diphenylthiocarbazone $\left(\mathrm{H}_{2} \mathrm{D}_{\mathrm{Z}}\right)$ is an organic chelating reagent that was initially used for calorimetric determination of trace metal ions [11]. It was discovered by Helmuth Fischer, and the vast potential of dithizone has been reveiled in 1925 [12]. Through the years, applications of dithizone become widely used and continue to be expended in many analytical researches. Due to its capability in exhibit ions interesting redox chemistry, the electrochemical behaviour of dithizone has been studied [13]. With the presence of azo and sulfhydryl groups, the oxidation and reduction of dithizone can be characterized. Previous studies shown that dithizone has been exploited in chemically modified electrode as a modifier for determination of metal ions [14-15].

In this study, the immobilization of dithizone as a polymerized polyvinyl chloride (PVC) membrane was carried out in order to improve the stability and sensitivity of the reagent. PVC act as a polymer matrix that can be easily incorporated with an ionophore, and was commonly used in many electrochemical studies [16 - 17]. It was first investigated by Heineman and coworkers in 1980, which demonstrated the application of polymer film in chemically modified electrode [18]. A platinum (Pt) disk composed of PVC film impregnated with valinomycin can offer high selectivity and electrochemical activity on the PPy/PPS layer [19]. The modified electrode showed a stable standard potential of potassium ion. Recently, studies of PVC film coated in Pt electrode for the determination of chromium showed good detection limit of $6.8 \times 10^{-8} \mathrm{M}$ with linear concentration range of $8.4 \times 10^{-}$ ${ }^{8} \mathrm{M}-1.0 \times 10^{-2} \mathrm{M}$. The sensor was successfully developed with the fast response time in $10 \mathrm{~s}$ [20]. Therefor, a new modified Ag electrode coated with polymerized chemisorption dithizone-PVC membrane as an electroactive reagent has been investigated. The electrochemical behaviour of the modified Ag electrode was described using cyclic voltammetric technique with several parameters studied.

\section{Chemicals and reagent}

\section{Materials and Methods}

All chemicals and reagent were of analytical grade and were used without further purification. Dithizone was obtained from Merck, Darmstadt, Germany. All metal salts, Copper (II) Sulphate, Iron (II) Chloride and Lead (II) Sulphate were of analytical grade from R \& M Marketing, Essex, U.K. Other chemicals were polyvinyl chloride (PVC) from Sigma-Aldrich, tributyl phosphate (TBP), tetrahydrofuran (THF), sodium tetraphenylborate $\mathrm{NaB}\left(\mathrm{C}_{6} \mathrm{H}_{5}\right)_{4}$ and hydrochloric acid $(\mathrm{HCl})$ from Merck Darmstadt, Germany. Deionized water was used throughout the preparation of the samples.

\section{Instrumentation}

Electrochemical measurements were performed using Autolab model PGSTAT30 from Metrohm Ltd, Herisau, Switzerland.

\section{Preparation of modified Ag electrode}

Initially, dithizone-PVC membrane was prepared by mixing $120 \mathrm{mg}$ of PVC powder, $10 \mathrm{mg}$ of dithizone as ionophore and $1.5 \mathrm{mg}$ of $\mathrm{NaB}\left(\mathrm{C}_{6} \mathrm{H}_{5}\right)_{4}$ as a lipophilic additive with $240 \mathrm{mg}$ of TBP. The mixture was dissolved in 6 $\mathrm{ml}$ of THF and was stirred for 3 hours. At the mean time, Ag electrode was polished repeatedly with sandpaper and was then thoroughly rinsed with acetone and followed by distilled water. Then, the Ag electrode was dipped into the dithizone-PVC membrane cocktail prepared, for $10 \mathrm{~s}$. Finally, the modified Ag electrode was dried at room temperature for 1 hour before use.

\section{Characterization of modified Ag electrode using cyclic voltammetry}

All measurements were done using a conventional three electrode system. A Ag electrode modified with a dithizone-PVC membrane coating was used as a working electrode with a surface area of $0.60 \mathrm{~cm}^{2}$. The Pt electrode and $\mathrm{Ag} / \mathrm{AgCl}$ electrode were used as auxiliarly and reference electrodes, respectively. All electrochemical 
experiments were carried out at room temperature and the potential was scanned in the range of -0.6 to $+0.6 \mathrm{~V}$ at $0.1 \mathrm{Vs}^{-1}$.

\section{Electrochemical characterization}

\section{Results and Discussion}

The modified Ag electrode with dithizone-PVC membrane was characterized using cyclic voltammetry (CV) with and without the presence of metal ions containing $0.1 \mathrm{M} \mathrm{KCl}$ as supporting electrolyte. The $\mathrm{CV}$ was performed using a potential range between -0.6 to $+0.6 \mathrm{~V}$ (vs. $\mathrm{Ag} / \mathrm{AgCl}$ ) with the scan rate of $0.1 \mathrm{~V} \mathrm{~s}^{-1}$. The voltammogram is represented in Figure 1. Line (a) shows the response of dithizone modified Ag electrode without metal ion, line (b), (c) and (d) show the responses of dithizone modified $\mathrm{Ag}$ electrode with $1 \times 10^{-3} \mathrm{M} \mathrm{Cu}^{2+}, \mathrm{Pb}^{2+}$ and $\mathrm{Fe}^{2+}$, respectively. For modification of $\mathrm{Ag}$ electrode with $\mathrm{Cu}^{2+}$, two reduction peaks can be observed from -0.1 to $-0.3 \mathrm{~V}$, corresponds to the two-electron reduction of $\mathrm{Cu}(\mathrm{II})$ to $\mathrm{Cu}(\mathrm{I})$ and $\mathrm{Cu}(0)$ (eq. 1 and Eq. 2). However, only one oxidation peak was observed at $+0.2 \mathrm{~V}$ corresponding to the deposition of $\mathrm{Cu}(0)$ to $\mathrm{Cu}(\mathrm{I}) / \mathrm{Cu}(\mathrm{II})$ [21]. The proposed mechanism is illustrated as below:

$$
\begin{array}{ll}
\mathrm{Cu}^{2+}+\mathrm{e}^{-} \longrightarrow \mathrm{Cu}^{+} \\
\mathrm{Cu}^{+}+\mathrm{e}^{-} \longrightarrow \mathrm{Cu}^{0}
\end{array}
$$

The same reduction peaks also can be seen in modified $\mathrm{Ag}$ electrode with $\mathrm{Pb}^{2+}$ and $\mathrm{Fe}^{2+}$ from the range of -0.14 to $0.35 \mathrm{~V}$ and -0.15 to $-0.36 \mathrm{~V}$ respectively. The reduction process for each metal ion showed that the dithizone-PVC membrane incorporates well with metal ions on the electrode surface, thus improved the electrode's performance. Meanwhile, the oxidation peak for modified $\mathrm{Ag}$ electrode with $\mathrm{Pb}^{2+}$ and $\mathrm{Fe}^{2+}$ was observed at $+0.30 \mathrm{~V}$ and $+0.20 \mathrm{~V}$, respectively.

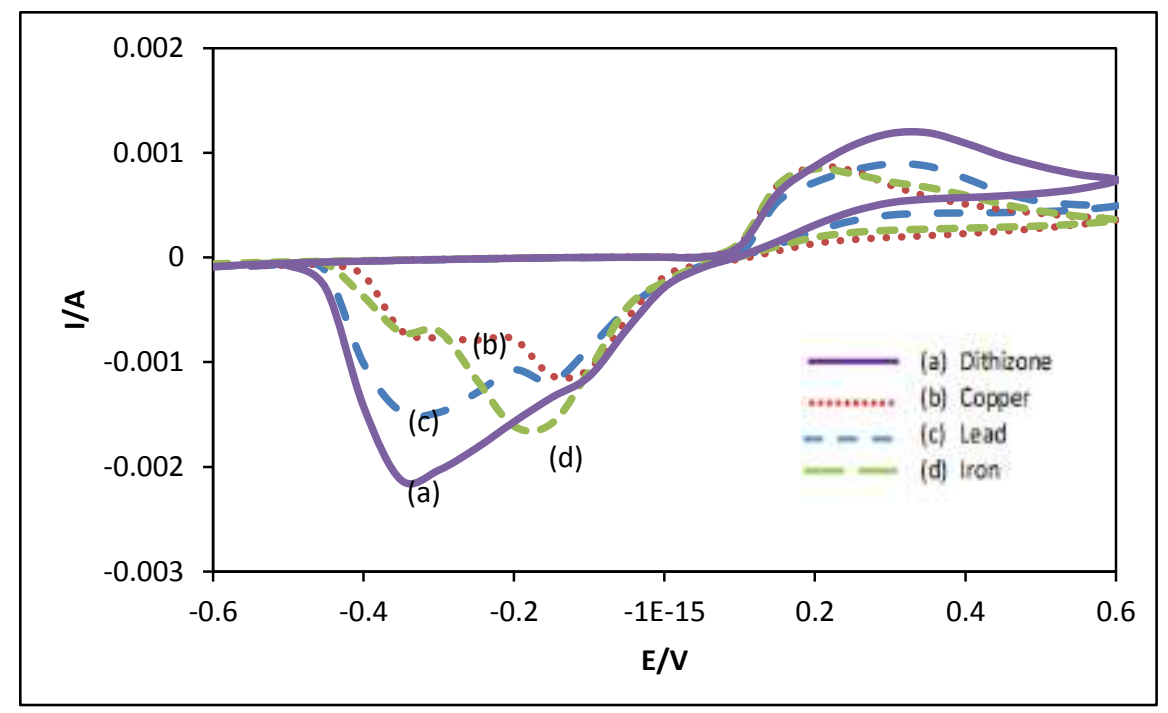

Figure 1. Cyclic voltammograms of (a) dithizone modified Ag electrode without metal (b) dithizone modified Ag electrode in $\mathrm{Cu}^{2+}$, (c) dithizone modified $\mathrm{Ag}$ electrode in $\mathrm{Pb}^{2+}$, and (d) dithizone modified $\mathrm{Ag}$ electrode in $\mathrm{Fe}^{2+}$.

\section{Effect of scan rates}

In cyclic voltammetry, scan rate was used to determine the electrochemical behavior of a species generated at the modified electrode [22]. In this research, scan rate were optimized in order to characterized the redox reaction. Figure 2 (a), (b) and (c) show the effect of scan rates on the voltammogram of modified Ag electrode in the 
potential range of 0.1 to $0.3 \mathrm{Vs}^{-1}$ for $\mathrm{Cu}^{2+}, \mathrm{Pb}^{2+}$ and $\mathrm{Fe}^{2+}$. Increasing the potential scan rate influenced the change of peak current in both redox reactions. As it can be seen, the change of peak current in cathodic reaction shifted to more negative value with the increasing of scan rates for all metal ions.

(a)

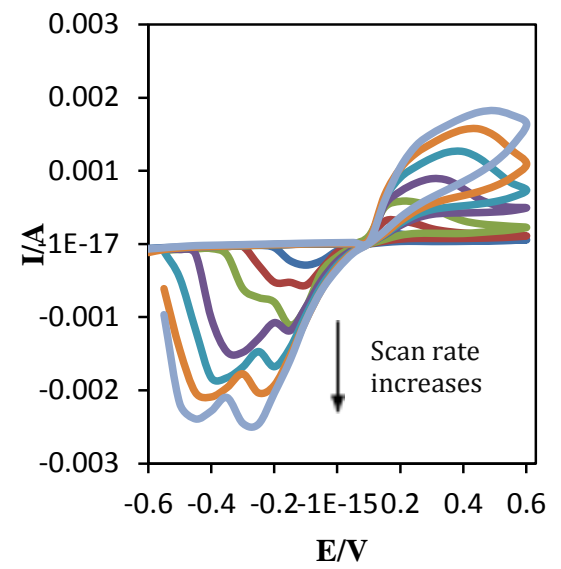

(b

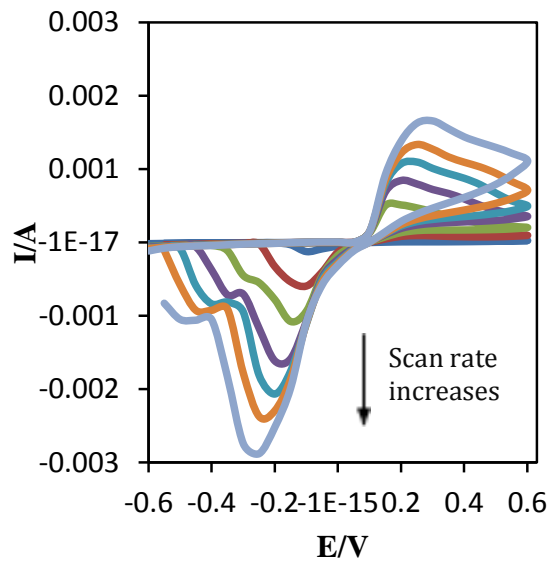

(c)

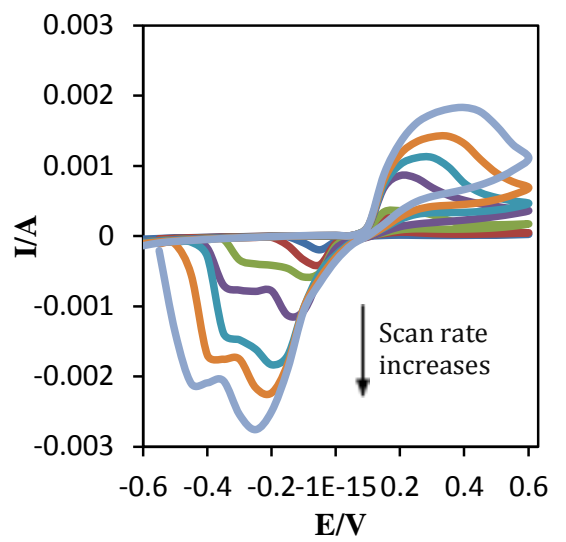

Figure 2. Optimization of scan rates on cyclic voltammograms of dithizone modified Ag electrode in $1 \times 10^{-3} \mathrm{M}$ of (a) $\mathrm{Pb}^{2+}$, (b) $\mathrm{Fe}^{2+}$ and (c) $\mathrm{Cu}^{2+}$ with $0.1 \mathrm{M} \mathrm{KCl}$ as supporting electrolyte. $(0.01 \mathrm{~V}, 0.025 \mathrm{~V}, 0.05 \mathrm{~V}, 0.1 \mathrm{~V}$, $0.15 \mathrm{~V}, 0.2 \mathrm{~V}$ and $0.3 \mathrm{~V})$.

The relationship between peak current densities, $\mathrm{i}_{\mathrm{p}}$, and peak on the square root of scan rate $\left(v^{1 / 2}\right)$, can be determined using the Randles-Sevcik equation (Eq. 3) [23].

$$
\mathrm{i}_{\mathrm{p}} \quad=\left(2.69 \times 10^{5}\right) \mathrm{n}^{3 / 2} \mathrm{AD}^{1 / 2} v^{1 / 2} \mathrm{C}
$$

where $\mathrm{n}$ is the number of electrons passed per molecule, $\mathrm{A}$ is the electrode area (in $\mathrm{cm}^{2}$ ), D is the diffusion coefficient of analytes (in $\mathrm{cm}^{2} \mathrm{~s}^{-1}$ ) and $\mathrm{C}$ represents the concentration of analytes (in mol cm${ }^{-3}$ ). A graph on peak current densities $\left(\mathrm{i}_{\mathrm{p}}\right)$ vs. square root of scan rate $\left(v^{1 / 2}\right)$ was illustrated in Figure 3. The results show that the linear 
relationships were obtained with the $\mathrm{i}_{\mathrm{p}}$ is proportional to $v^{1 / 2}$ which indicates that the mechanism of mass transfer occurs from the bulk of the metal ion solution to the electrode surface by diffusion process. This behavior indicates that the electrochemical process was diffusion controlled [24-25].

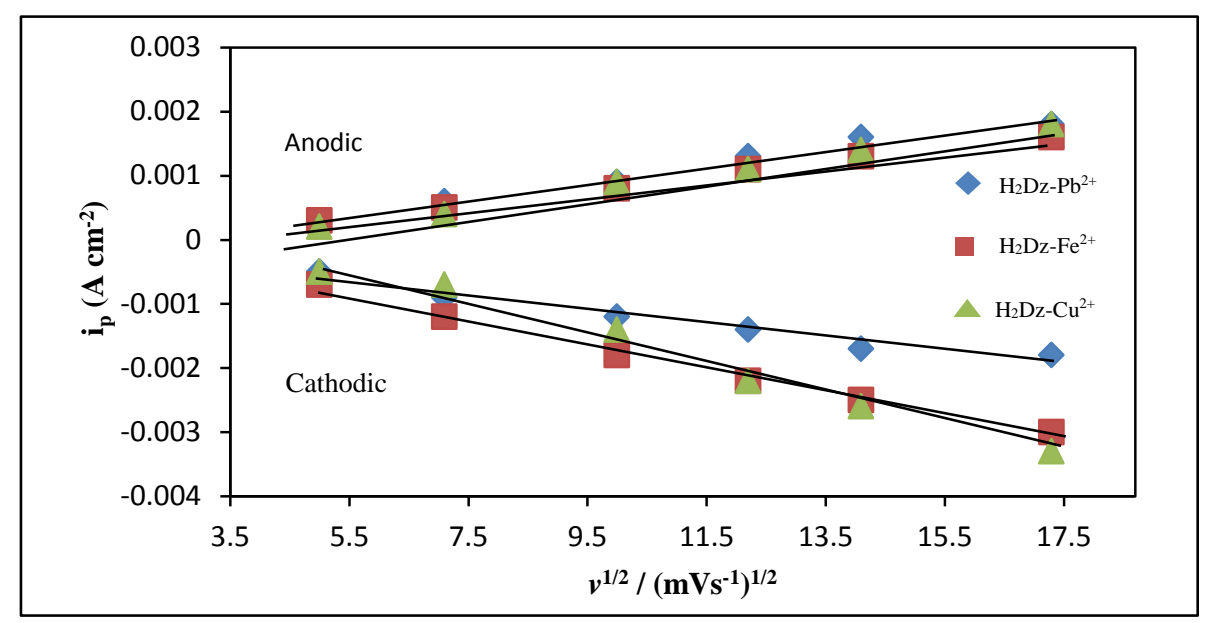

Figure 3. The relationship between peak current densities $\left(\mathrm{i}_{\mathrm{p}}\right.$ ) on the $v^{1 / 2}$ for the $\mathrm{H}_{2} \mathrm{Dz}$ modified $\mathrm{Ag}$ electrode in $1 \times 10^{-3} \mathrm{M}$ of $\mathrm{Pb}^{2+}, \mathrm{Fe}^{2+}$ and $\mathrm{Cu}^{2+}$.

\section{Effect of different concentration}

In order to investigate the influence of metal ions concentration on the cyclic voltammogram, study on different concentrations of metal ions $\mathrm{Pb}^{2+}, \mathrm{Fe}^{2+}$ and $\mathrm{Cu}^{2+}$ were carried out. Figure 4 (a), (b) and (c) show the cyclic voltammogram for concentration of metal ions from $2 \times 10^{-5} \mathrm{M}$ to $10 \times 10^{-5} \mathrm{M}$ in $0.1 \mathrm{KCl}$ at the scan rate of 0.1 $\mathrm{Vs}^{-1}$. As can be seen from the figure, the anodic and cathodic peak current increase with the increasing of concentration. This indicates the concentration of metal ion $\mathrm{Pb}^{2+}, \mathrm{Fe}^{2+}$ and $\mathrm{Cu}^{2+}$ are proportional to the electrochemical peak current.
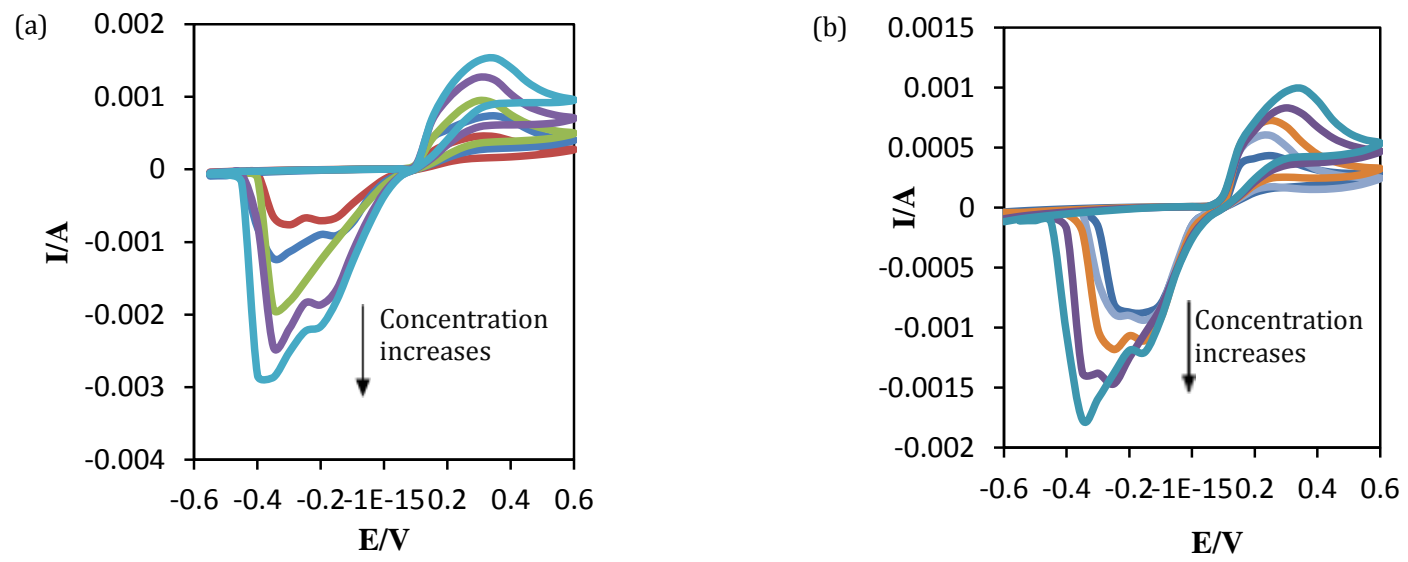
(C)

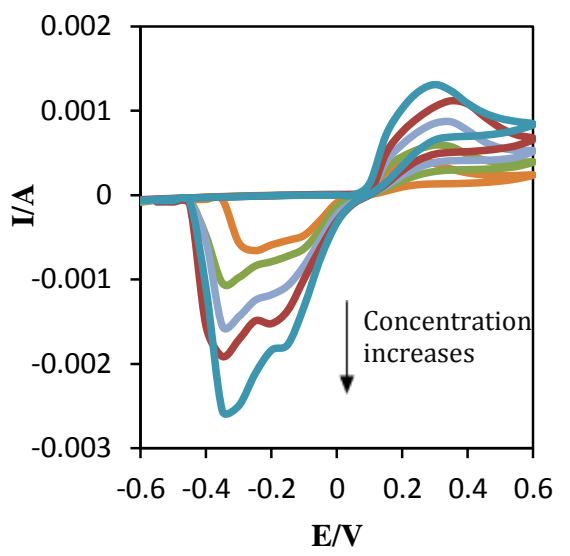

Figure 4. Cyclic voltammograms of different concentration of metal ions (a) $\mathrm{Pb}^{2+}$, (b) $\mathrm{Fe}^{2+}$ and (c) $\mathrm{Cu}^{2+}$ deposited on the dithizone modified Ag electrode. ( $2 \times 10^{-5} \mathrm{M}, 4 \times 10^{-5} \mathrm{M}, 6 \times 10^{-5} \mathrm{M}, 8 \times 10^{-5} \mathrm{M}$ and $\left.10 \times 10^{-5} \mathrm{M}\right)$.

(a)

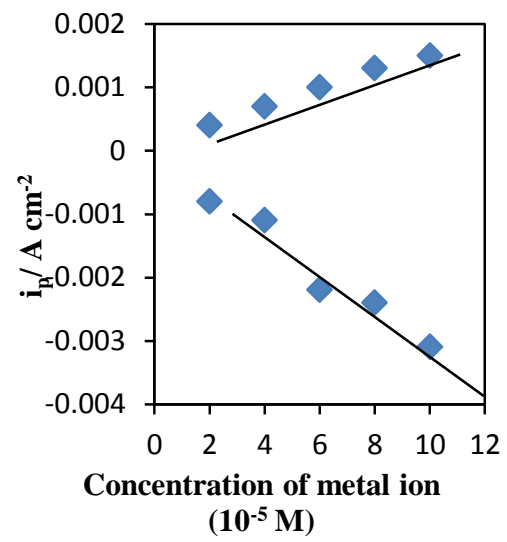

(b)

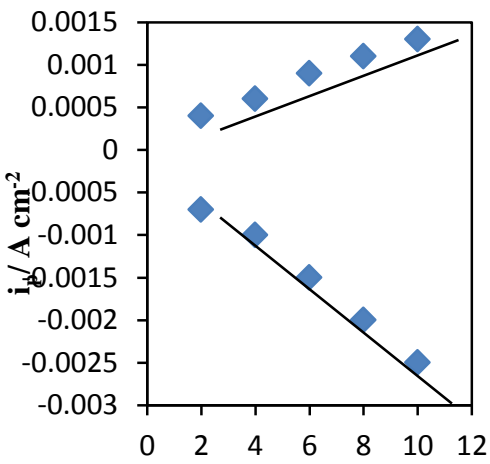

Concentration of metal ion $\left(10^{-5} \mathrm{M}\right)$

(c)

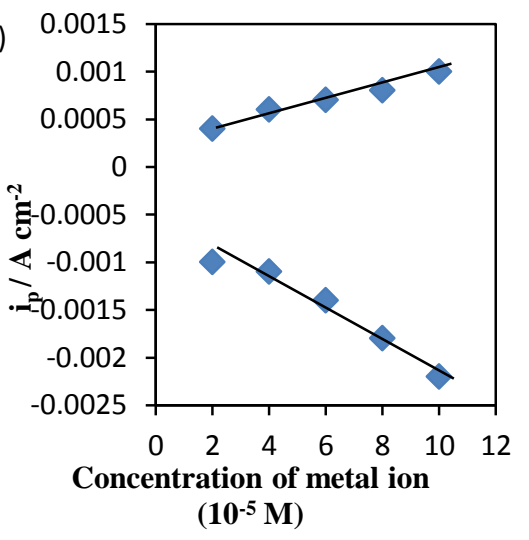

Figure 5. The relationship between peak current densities ( $\mathrm{i}_{\mathrm{p}}$ ) on concentration of metal ions (a) $\mathrm{Pb}^{2+}$, (b) $\mathrm{Fe}^{2+}$ and (c) $\mathrm{Cu}^{2+}$ at dithizone modified $\mathrm{Ag}$ electrode. 


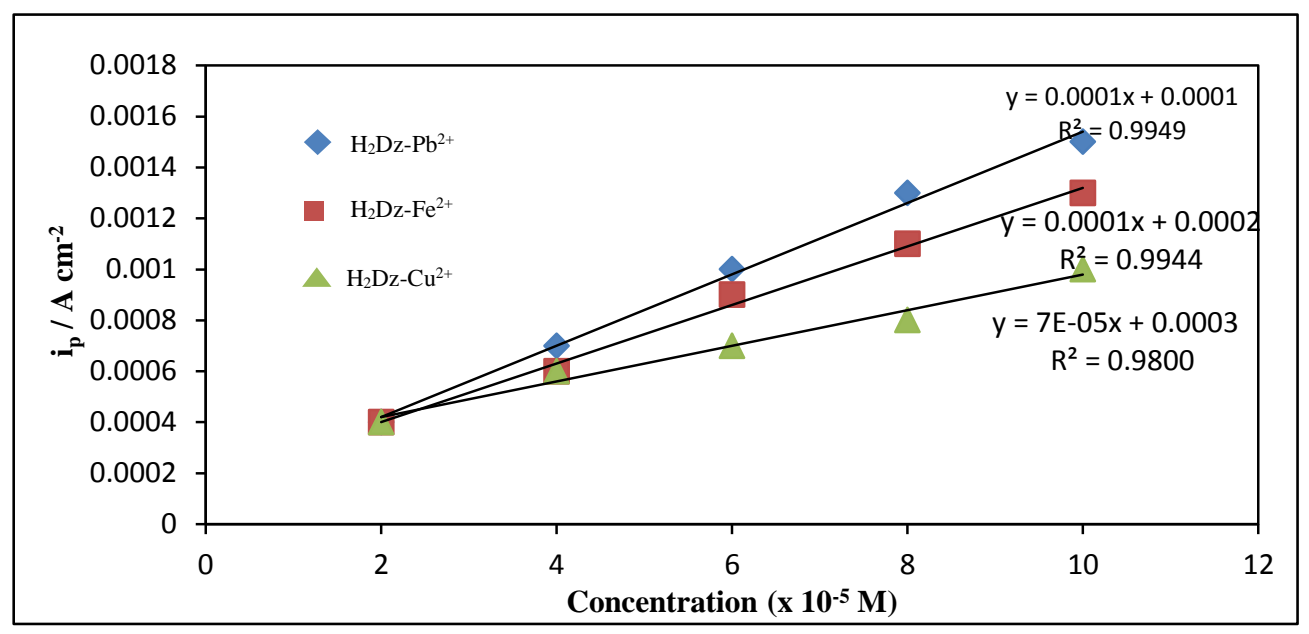

Figure 6. Calibration graph of peak current, $\mathrm{i}_{\mathrm{p}}$ versus the concentration of metal ions using $\mathrm{H}_{2} \mathrm{Dz}$ modified $\mathrm{Ag}$ electrode in $0.1 \mathrm{M} \mathrm{KCl}$ as supporting electrolyte.

\section{Limit of Detection (LOD)}

A calibration graph for the response of dithizone modified $\mathrm{Ag}$ electrode towards the metal ion $\mathrm{Cu}^{2+}, \mathrm{Fe}^{2+}$ and $\mathrm{Pb}^{2+}$ has been plotted in Figure 6 to determine the sensitivity of the system. Within the potential range of -0.6 to $+0.6 \mathrm{~V}$, the correlation coefficient observed for $\mathrm{Cu}^{2+}, \mathrm{Fe}^{2+}$ and $\mathrm{Pb}^{2+}$ were $0.9800,0.9944$ and 0.9949 . From the results obtained, the evaluated values for LOD were $8.3 \times 10^{-7} \mathrm{M}, 4.7 \times 10^{-7} \mathrm{M}$ and $7.6 \times 10^{-7} \mathrm{M}$, respectively.

\section{Conclusion}

The modification of $\mathrm{Ag}$ electrode based on dithizone as an ionophore reagent has been successfully developed to determine the concentration of $\mathrm{Pb}^{2+}, \mathrm{Fe}^{2+}$ and $\mathrm{Cu}^{2+}$ in aqueous solutions. The modification using immobilized dithizone in PVC membrane via chemisorptions on the surface of Ag electrode exhibited irreversible process in a wide potential range from -0.6 to $+0.6 \mathrm{~V}$. The system showed excellent electrochemical characteristics with a good limit of detection in the range of $4.7 \times 10^{-7} \mathrm{M}$ to $8.3 \times 10^{-7} \mathrm{M}$ for those three metal ions studied. Hence, a new chemically modified electrode for detection of $\mathrm{Pb}^{2+}, \mathrm{Fe}^{2+}$ and $\mathrm{Cu}^{2+}$ based on dithizone modified $\mathrm{Ag}$ electrode has been developed.

\section{Acknowledgement}

The authors would like to acknowledge Universiti Malaysia Terengganu and Ministry of Higher Education (MOHE) for the funding of this study (RAGS).

\section{References}

1. Schwartz, M. S., Benci, J. L., Selote, D. S., Sharma, A. K., Chen, A. G. Y., Dang, H., Fares, H., Vatamaniuk, O. K. (2010). Detoxification of multiple heavy metals by a half-molecule ABC transporter, HMT-1, and coelomocytes of Caenorhabditis elegans. PLoS ONE 5 (3): e9564.

2. Reeve, R. N. (2002). Introduction to Environmental analysis. ( $1^{\text {st }}$ ed.) John Wiley \& Sons Ltd.

3. Zejli, H., Sharrock, P., Hidalgo-Hidalgo de Cisneros, J. L., Naranjo-Rodriguez, I. and Temsamani, K. R. (2005). Voltammetric determination of trace mercury at a sonogel-carbon electrode modified with poly-3methylthiophene. Talanta 68: $79-85$.

4. Pournaghi-Azar, M. H. and Dastangoo, H. (2003). Electrochemical behavior of a novel palladium pentacyanonitrosylferrate modified aluminum electrode. Electrochimica Acta 48: 1797 - 1806.

5. Prieto-Simon, B. and Fabregas, E. (2004). Comparative study of electron mediators used in the electrochemical oxidation of NADH. Biosensor Bioelectron 19: 1131 - 1138. 
6. Faucheux, N., Schweiss, R., Lutzow, K., Werner, C. and Groth, T. (2004). Self-assembled monolayers with different terminating groups as model substrates for cell adhesion studies. Biomaterials 25: 2721 -2730.

7. Wang, H., Xu, G. and Dong, S. (2001). Electrochemistry and electrochemiluminescence of stable (2,2'bipyridyl)ruthenium(II) monolayer assembled on benzene sulfonic acid modified glassy carbon electrode. Talanta 55: $61-67$.

8. Kan, J., Pan, X. and Chen, C. (2004). Polyaniline-uricase biosensor prepared with template process. Biosensor Bioelectron 19: 1635 - 1640.

9. Calvo-Marzal, P., Torres, K., Hoehr, N., Neto, G. and Kubota, L. (2004). Determination of reduced gluthathione using an amperometric carbon paste electrode chemically modified with TTF-TCNQ. Sensor Actuat B 100: 337 - 344.

10. Toma, H. E., Zamarion, V. M., Toma, S. H. and Araki, K. (2010). The coordination chemistry at gold nanoparticles. Journal Brazilian Chemical Society 21 (7): 1158 - 1176.

11. Tomcsányim, L. (1974). Investigations on the redox character of dithizone by voltammetric methods. Part I. The reduction of dithizone in aqueous solutions. Analytical Chimica Acta 70: 411 - 416.

12. Karel, G. V. E. and Jannie, C. S. (2010). Chemical and electrochemical oxidation and reduction of dithizone. Polyhedron 29: 1727 - 1733.

13. Jeanne, E. P., and Richard, P. B. (1981). Dithizone adsorption at metal electrodes. Electrochemical characterization of dithizone anion at silver electrode. Journal of Electroanalytical Chemistry 132: 291 - 309.

14. Kalcher, K. and Fresenius, Z. (1986). Voltammetrisches Verhalten von Gold an einer Dithizon-modifizierten Kohlenpasteelectrode. Anaytical Chemistry 325: 181 - 185.

15. Labuda, J. and Plaskon, V. (1990). Determination of mercury ions on a diphenylcarbazone bulk modified graphite electrode. Analytica Chimica Acta 228: 259 - 263.

16. Abbaspour, A., and Izadyar, A. (2001). Highly selective electrode for Nickel (II) ion based on 1,5diphenylthiocarbazone (dithizone). Microchemical Journal 69: 7 - 11.

17. Singh, A. K., and Saxena, P. (2007). A PVC-based membrane electrode for nickel (II) ions incorporating a tetraazamacrocycle as an ionophore. Sensors and Actuators B 121: $349-355$.

18. Heineman, W. R., Wieck, H. J. and Yacynych, A. M. (1980). Polymer Film Chemically Modified Electrode as a Potentiometric Sensor. Analytical Chemistry. Analytical Chemistry 52: $345-346$.

19. Momma, T., Komaba, S., Yamamoto, M., Osaka, S. and Yamauchi, S. (1995). All-solid potassium-selective electrode using double-layer film of polypyrrole/polyanion composite and plasticized poly(vinyl chloride) containing valinomycin. Sensors and Actuators B24-B25: 724 - 728.

20. Abbaspour, A., Refahi, M., Khalafi-Nezhad, A., Rad, N. S. and Behrouz, S. (2010). Carbon composite-PVC based membrane coated platinum electrode for chromium determination. Journal of Hazardous Materials 184: $20-25$.

21. Eliane, R. D. S., Edmar, P. M., Elizabeth, N. F., Jiujun, Z. and Aldalea, L. B. M. (2006). Graphite electrodes modified by 8-hydroxyquinolines and its application for the determination of copper in trace levels. Journal Brazilian Chemical Society 17: $177-183$.

22. Alice, D. L. (2011). Electrochemical analysis supported by macro and microelectrode array. Durham University, Durham, United kingdom.

23. Somerset, V., Leaner, J., Mason, R., Iwuoha, E. and Morrin, A. (2010). Development and application of poly(2,2-dithiodianiline) (PDTDA) coated screen-printed carbon electrode in inorganic mercury determination. Electrochemical Acta 55: 4240 - 4246.

24. Daud, N., Yusof, N. A., Nor, S. M. M. (2013). Electrochemical characteristic of biotinyl somatostation14/Nafion modified gold electrode in development of sensor for determination of $\mathrm{Hg}(\mathrm{II})$. International Journal Electrochemical Science 8: 10086 - 10099.

25. Afkhami, A., Felehgari, F. S. and Madrakian, T. (2013). Gold nanoparticles modified carbon paste electrode as an efficient electrochemical sensor for rapid and sensitive determination of cefixime in urine and pharmaceutical samples. Electrochemical Acta 103: 125 - 133.

26. Zaky, A. M., Abd El-Rehim, S. S. and Mohamed, B. M. (2006). Effect of addition of sulphide ions on the electrochemical behavior and corrosion of $\mathrm{Cu}-\mathrm{Ag}$ Alloys in alkaline solutions. International Journal Electrochemical Science 1: 17 - 31.

27. Riyanto., Othman, M, R. and Salimon, J. (2007). Analysis of ethanol using copper and nickel sheet electrodes by cyclic voltammetry. Malaysian Journal of Analytical Sciences 11 (2): 379 - 387. 